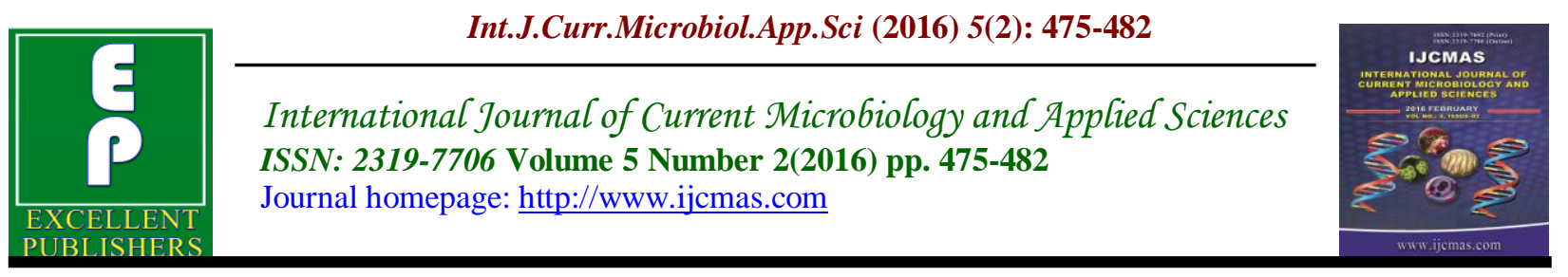

Original Research Article

doi: http://dx.doi.org/10.20546/ijcmas.2016.502.053

\title{
Hypotensive Effect of an Aqueous Extract from Heliotropium indicum Linn. 1753 (Boraginaceae)
}

\section{ZAHOUI Ouga Stanislas*, NENE BI Semi Anthelme, SORO Tianga Yaya and TRAORE Flavien}

\author{
Department of Physiology, U.F.R Biosciences, University Felix Houphouet-Boigny, \\ 22 B.P. 582 Abidjan 22, Côte d'Ivoire \\ *Corresponding author
}

\begin{tabular}{|c|c|}
\hline & A B S T R A C T \\
\hline $\begin{array}{l}\text { Heliotropium } \\
\text { indicum, } \\
\text { Hypotensive } \\
\text { potential, } \\
\text { Hypertensive } \\
\text { effect }\end{array}$ & \multirow{3}{*}{$\begin{array}{l}\text { The use of Heliotropium indicum for the treatment of various conditions has } \\
\text { been demonstrated by many précedants works. The aim of this present study } \\
\text { was to demonstrate the hypotensive potential of this plant. Starting from an } \\
\text { animal model, we were able to show that this aqueous extract at doses } \\
\text { ranging between } 3.51 \times 10^{-3} \text { and } 3.75 \times 10^{-2} \mathrm{~g} / \mathrm{kg} \mathrm{bw} \text {, induced a sustained } \\
\text { hypotension (dose-dependent) similar to that caused by acetylcholine (Ach) } \\
\text { at doses ranging from } 5.6 \times 10^{-7} \mathrm{~g} / \mathrm{kg} \text { body weight and } 5.5 \times 10^{-4} \mathrm{~g} / \mathrm{kg} \text { body } \\
\text { weight in rabbits. The study of the interaction between Adrenaline (Adr), a } \\
\text { hypertensive reference molecule to } 2.5 \times 10^{-5} \mathrm{~g} / \mathrm{kg} \text { bw and aqueous extract of } \\
\text { Heliotropium indicum (AEH) showed that the extract has significantly } \\
\text { reduced the hypertension induced by Adr. These results indicated that the } \\
\text { aqueous Heliotropium indicum extract had a hypotensive potential. The } \\
\text { traditional use of this plant to treat arterial hypertension was justified. }\end{array}$} \\
\hline Article Info & \\
\hline $\begin{array}{l}\text { Accepted: } \\
\text { 23 January } 2016 \\
\text { Available Online: } \\
\text { 10, February } 2016\end{array}$ & \\
\hline
\end{tabular}

\section{Introduction}

Heliotropium indicum Linn, 1753 (Boraginaceae) commonly called "herbe papillon" or "herbe à verrues" in French, "Indian heliotrope" or "Cock's Comb" in English is a medicinal plant that intervenes in the treatment of several diseases in subSaharan Africa (Keita et al., 1999).

The decoction is used to activate the work of Women in child birth and given to people who suffer from heart or stomach (Adjanohounand AKE-ASSI, 1979) in Côte d'Ivoire.
The juice of this plant is also used as antigonococcal and anti-diarrheal (Kalanda and Omasombo, 1995; Traore et al., 2007).

In Senegal the "Wolof" and "Lebu" use the powdered leaves to treat various skin diseases specifically eczema and impetigo in children (Adjanohoun et al., 1989). He enters in to the treatment of the fading and of syncope (Bouquet and Debray, 1974). It is also used against malaria. 
The pharmacological tests showed that the methanol extract of the leaves of Heliotropium indicum shows antiinflammatory activity (Srinivas et al., 2000) and curative in rats (Srinivasan, 2001; Reddy et al., 2002) and the alcoholic extract also has antimicrobial activity (Rao et al., 2006). Kamanzi et al., 2002 showed that the methanol extract of the leaves of this plant has larvicidal properties on Aedes aegypti.

The purpose of this study is to highlight the hypotensive potential of the aqueous extract of Heliotropium indicum in order to justify its use in the treatment of hypertension.

\section{Materials and Methods}

\section{Plant Material}

The plant material used is the leaves of Heliotropium indicum (Boraginaceae), purchased from the herbalists of Adjamé market (Abidjan). The plant material was identified and authenticated by Professor Laurent AKE-ASSI, the Plant Biology Laboratory, from the herbarium of the National Floristic Center of University Felix Houphouet Boigny-Abidjan (Côte d'Ivoire). A voucher specimen (herbarium No. 10411 of December 12, 1968).

\section{Extraction Method of Freeze-dried Aqueous Extract}

Fifty grams of the leaves were dried in the shade at room temperature between $26^{\circ} \mathrm{C}$ and $30^{\circ} \mathrm{C}$, and powdered with a microcrusher. The powder obtained $(50 \mathrm{~g})$ was macerated for 24 hours in a 1 liter of distilled water using magnetic stirrer. The supernatant was filtered with Whatman No 1 filter paper $(3 \mathrm{~mm})$ and it was evaporated using rotating evaporator. The solvent was completely removed under reduced pressure to obtain a dry mass. The aqueous extract of
Heliotropium indicum obtained was stored at $-5^{\circ} \mathrm{C}$. The concentrations to be tested were prepared extemporaneously by dilution in the Mac Ewen (ME) a physiological solution.

\section{Extraction Method Decoction}

Seventy grams of the dried bark powder of this plant were mixed with $800 \mathrm{ml}$ of water. The whole mixture was boiled for 30-45 minutes. The decoction obtained was approximately $500 \mathrm{ml}$. The decoction was then filtered on Whatman No 1 filter paper (3 mm) paper and hydrophilic cotton subsequently. The filtrate obtained was evaporated under vacuum at $70^{\circ} \mathrm{C}$ using a Rotavapor evaporator type "Bucchi". The resulted paste was frozen and lyophilized.

\section{Animal Material}

The animals used for the experiments were rabbits of Oryctolagus cuniculus species. They were used to study the action of this extract on blood pressure variation. The rabbits used weighed an average of $2 \pm 0.2$ $\mathrm{kg}$. They came from different farms around Abidjan. Also they were acclimated for seven days at the pet guage of UFR Biosciences, University Félix HouphouetBoigny, to regulate and harmonize their physiological state before the experiments. The animals were treated according to the principles of scientific ethics committee of Biology, on the use of laboratory animals in experimental tests.

\section{Chemicals and Saline Chemical Products}

During this work, chemicals were used viz: Acetylcholine (Ach) (Prolabo, France), Adrenaline (Adr) (Prolabo, France).

\section{Saline}

During this study, mammals were fed with normal saline - Mac Ewen at $\mathrm{pH}$ 7.4. It 
contains $\mathrm{NaCl} 122 \mathrm{mM}$; $\mathrm{KCl} 4.9 \mathrm{mM} ; \mathrm{CaCl}_{2}$ $2.52 \mathrm{mM} ; \mathrm{NaPO}_{4} \mathrm{H}_{2} 1.18 \mathrm{mM} ; \mathrm{NaHCO}_{3}$ $15.5 \mathrm{mM} ; \mathrm{MgCl}_{2} 1.2 \mathrm{mM}$ and glucose 5.5 $\mathrm{mM}$.

\section{Experimental and Technical Apparatus for Recording Blood Pressure}

The experimental device used for recording blood pressure is the Ludwig gauge. The rabbit was anesthetized by éthyluréthane injection intra-peritoneally; dosed at $40 \%$ in the ratio of $1 \mathrm{~g} / \mathrm{kg}$ bw. Its carotid artery was exposed and intubated with a catheter connected to the manometer containing mercury. Changes in the pressure of the rabbit carotid artery were transmitted to the column of mercury. They were transcribed using a stylus listing, on a cylinder-coated paper containing lampblack. It was rotated at a constant speed. The test substances were dissolved in a solution of Mac Ewen and then injected into the rabbit (saphenous vein) before dissection.

\section{Expression of Results}

Effective Dose 50\% ( $\left.\mathrm{ED}_{50}\right)$ was expressed in grams of lyophilized aqueous extract per kilogram of body weight of the animal $(\mathrm{g} / \mathrm{kg}$ bw).

\section{Treatment of Experimental Results}

Recordings made on paper were smoky and tend to vanish very soon. To fix the soot it was scanned before being reversed; small corrections were done using Photo editor software and Microsoft Paint.

The statistical analysis of values and graphical representation of data were carried out respectively through Graph Pad Instat software (Microsoft, San Diego, California, United States) and GraphPad Prism 4 (Microsoft, San Diego, California, United States).
The statistical analysis such as analysis of variance (ANOVA), and multiple comparison Tukey Kramer test were performed on the obtained data with a level of significance at $\mathrm{P}<0.05$. All values were expressed with the standard error of the mean and presented as means \pm SEM.

\section{Place and Period of Study}

These experiments were conducted at the Laboratory of Animal Physiology of the University Felix Houphouet-Boigny (Côte d'Ivoire), between March 2008 and October 2008. Additional experiments were performed in April 2010.

\section{Results and Discussion}

The Effects of the Aqueous Extracts of Heliotropium indicum (AEH) on the Blood Pressure of Rabbits

Figure 1 shows the effects of aqueous extract of Heliotropium indicum(AEH) on blood pressure in the rabbits according to the dose. The rabbit had a normal blood pressure of a value of $108 \mathrm{~mm} \mathrm{Hg}$ in our experimental conditions.

Doses of AEH between $3.1 \times 10^{-4} \mathrm{~g} / \mathrm{kg}$ bw and $3.75 \times 10^{-2} \mathrm{~g} / \mathrm{kg}$ bw caused hypotension and increased blood pressure from $9.7 \pm 1.81$ $\mathrm{mm} \mathrm{Hg}$ to $36.66 \pm 3.62 \mathrm{~mm} \mathrm{Hg}$, which corresponds to a decrease in blood pressure of the normal rabbit from $8.98 \%(\mathrm{p}<0.05)$ to $33.94 \%$ ( $\mathrm{p}<0.001)$.

This experiment was performed several times $(\mathrm{n}=4)$ and the average values obtained have enabled us to obtain the curve in Figure $1 \mathrm{~B}$, reflecting the decrease in blood pressure of the rabbits according to the dose of AEH. This allowed a sigmoid graph formulation that determines the effective dose $50 \%\left(\mathrm{ED}_{50}\right)$ which is equal to $1.25 \times 10^{-2} \mathrm{~g} / \mathrm{kg}$ bw. 
Effects of Acetylcholine (Ach) on the Blood Pressure in Rabbits (Dose Dependent)

Figure 2 shows the effects of the administration of increasing doses of Ach on the blood pressure of rabbits. Normal blood pressure of rabbits under our experimental conditions was $120 \mathrm{~mm} \mathrm{Hg}$. Ach doses from $5.6 \times 10^{-5} \mathrm{~g} / \mathrm{kg}$ bw to $5.5 \times 10^{-2} \mathrm{~g} / \mathrm{kg}$ bw, caused a sustained dose-dependent hypotension, which varied from $45 \pm 3.27$ to $115 \pm 3.45 \mathrm{~mm} \mathrm{Hg}$. This corresponds to a decrease in the normal blood pressure between 37 and 95\% ( $p<0.001)$. This experiment was carried out several times (n $=3$ ) and the average values obtained, have enabled us to trace the curve of Figure $2 \mathrm{~B}$ which reflects the reduction in blood pressure of rabbits as a function of the dose of Ach. This sigmoid graph allowed the determination of an $\mathrm{ED}_{50}$ which is of $3 \times 10^{-}$ ${ }^{6} \mathrm{~g} / \mathrm{kg}$ bw. The $\mathrm{ED}_{50}$ of Ach, which is a reference molecule, that showed approximately 4000 times lower than the $\mathrm{ED}_{50}$ of $\mathrm{AEH}$ (the lyophilized aqueous extract of Heletropium indicum).

\section{Effects of AEH on Hypertension Induced by Adrenaline (Adr) in Rabbits}

Epinephrine was injected at $2.5 \times 10^{-5} \mathrm{~g} / \mathrm{kg}$ bw dosage level to the rabbits and induced a pressure of $76 \pm 3.57 \mathrm{~mm} \mathrm{Hg}$, which represents $100 \%$ increase in the initial level of blood pressure (Figure 3).

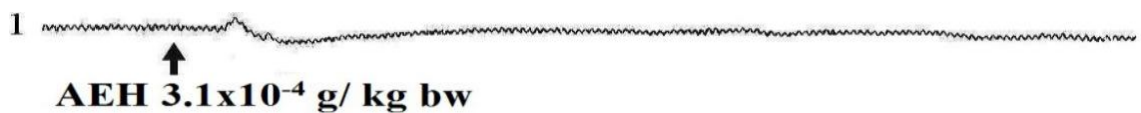

A

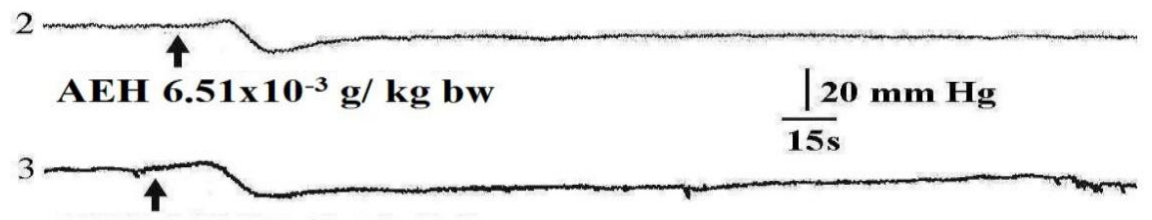

AEH $1.89 \times 10^{-2} \mathrm{~g} / \mathrm{kg}$ bw
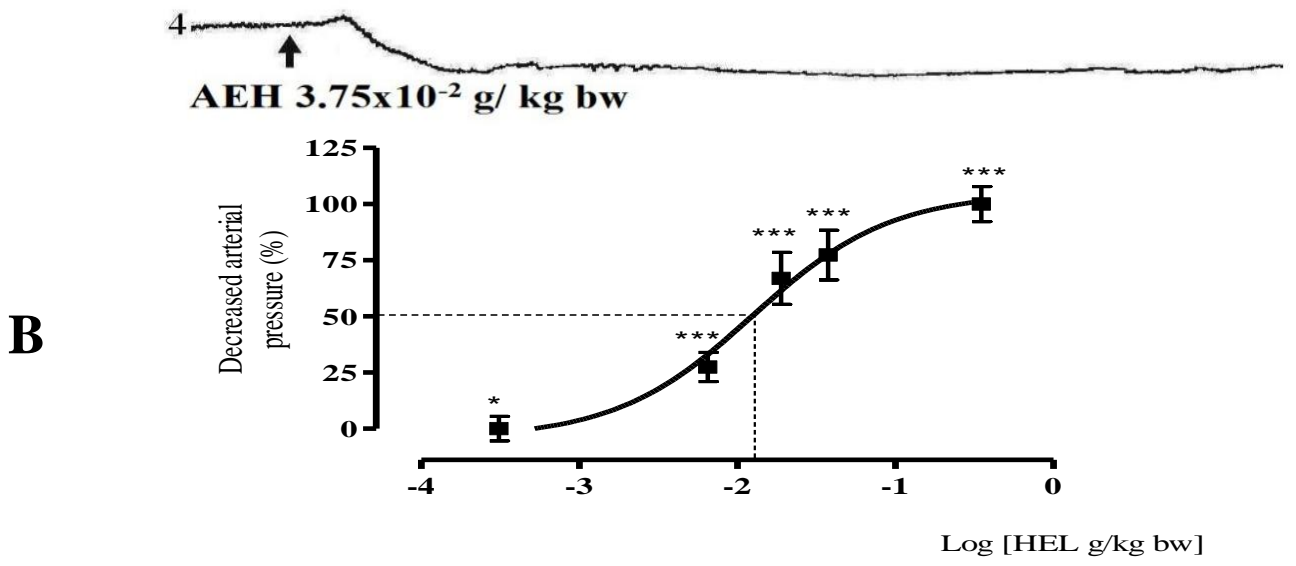

Figure.1 Effect of the Aqueous Extract of Heliotropium indicum on Blood Pressure of Rabbits as a Function of the Dose

\section{A - Effect of dose response AEH}

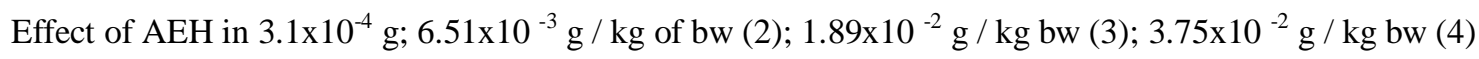

\section{B - Decreased blood pressure according to the dose of AEH}

The values express the maximum percentage decrease in pressure relative to normal blood pressure (Mean \pm SEM; $\mathrm{n}$ $=4 ; * \mathrm{P}<0.05, * * * \mathrm{p}<0.001)$. AEH causes a dose-dépendent hypotension; $\mathrm{ED}_{50}=1.25 \times 10^{-2} \mathrm{~g} / \mathrm{kg}$ bw 
A
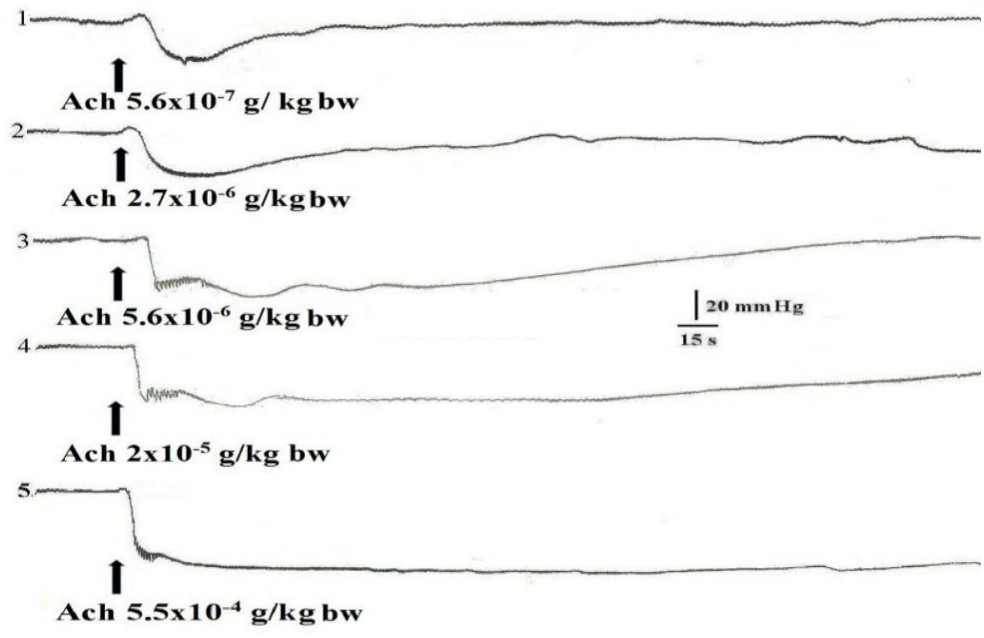

B

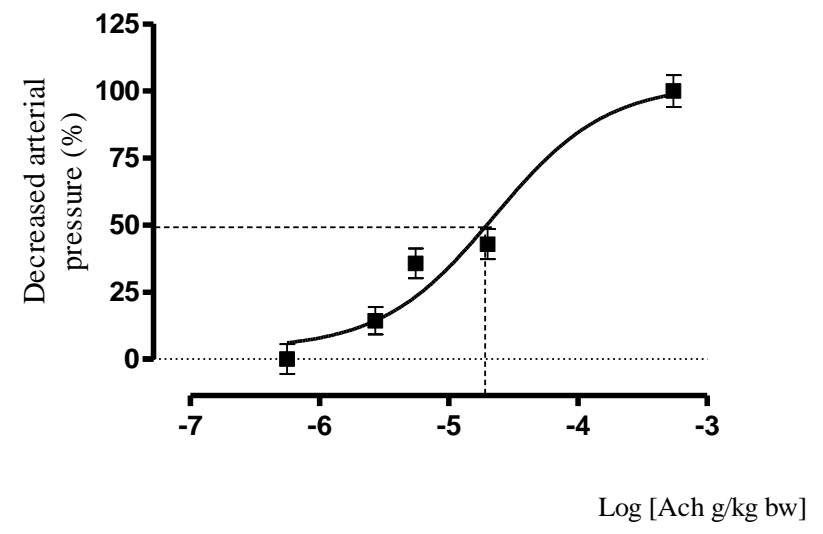

Figure.2 Effects of Ach on Blood Pressure of Rabbits as a Function of the Dose

\section{A - Effect of Ach Depending on the Dose}

Effect of Ach $5.6 \times 10^{-7} \mathrm{~g} / \mathrm{kg}$ bw (1); 2.7.10 ${ }^{-6} \mathrm{~g} / \mathrm{kg}$ bw (2); $5.5 \times 10^{-6} \mathrm{~g} / \mathrm{kg}$ bw (3); $2.10^{-5} \mathrm{~g} / \mathrm{kg}$ bw (4); $5.5 \times 10^{-4} \mathrm{~g} / \mathrm{kg}$ bw (5)

The Ach lowers blood pressure rabbit between $5.6 \times 10^{-5}$ and $5.5 \times 10^{-4} \mathrm{~g} / \mathrm{kg}$ bw

\section{B - Decreased Blood Pressure Rabbit According to the Dose of Ach}

The values express the maximum percentage decrease in pressure relative to normal blood pressure (mean \pm SEM; $\mathrm{n}$ $=4 ; * \mathrm{p}<0.05 ; * * \mathrm{p}<0.01 ; * * * \mathrm{p}<0.001)$

The Ach causes a dose-dependent hypotension, $\mathrm{ED}_{50}=3 \times 10^{-6} \mathrm{~g} / \mathrm{kg}$ bw 

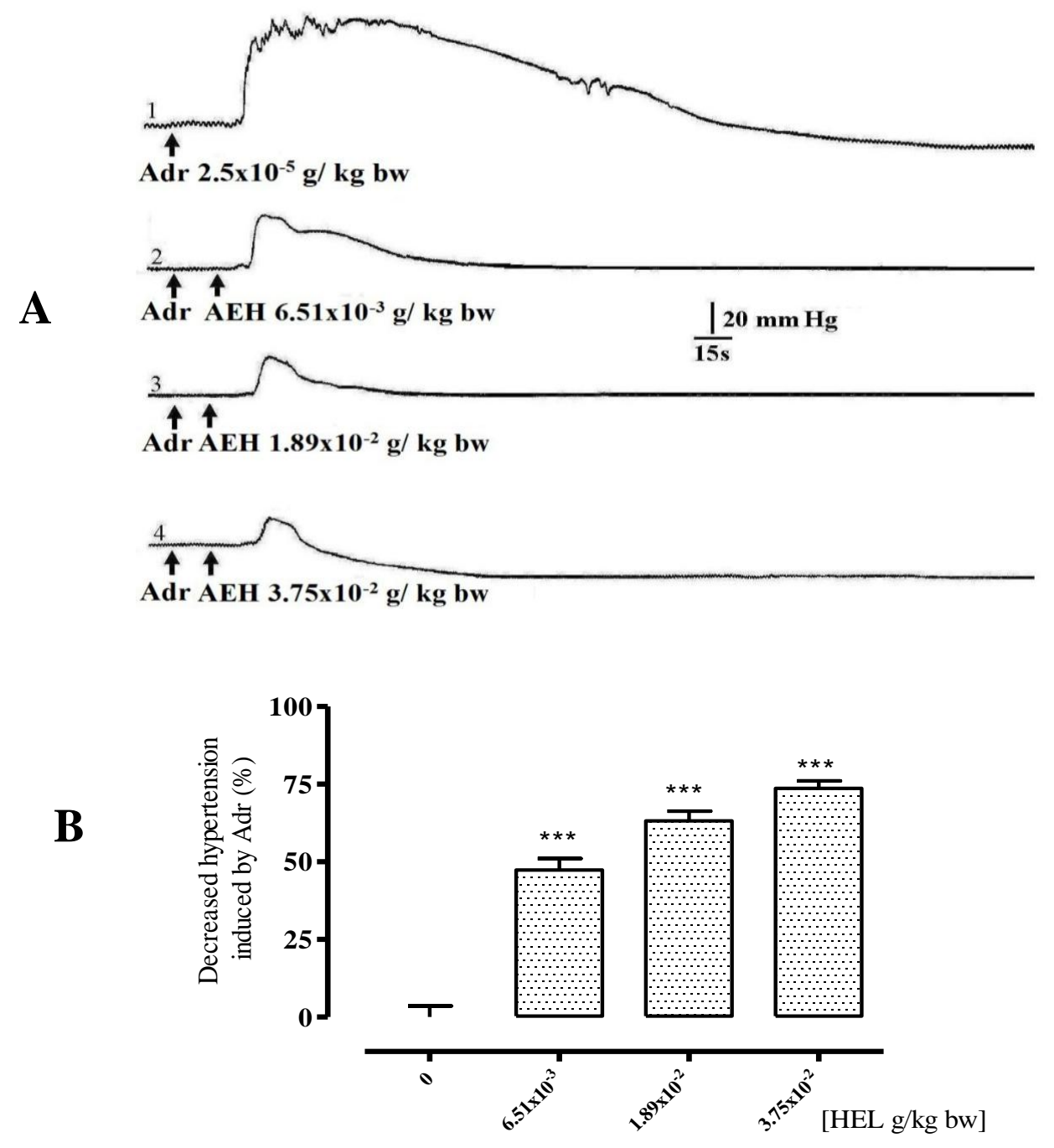

Figure.3 Effects of the Aqueous Extract of Heliotropium indicum on Hypertension Induced by Adrenaline in Rabbits

\section{A - Interaction Adr-AEH}

1 - Effect of Adr to $2.5 \times 10^{-5} \mathrm{~g} / \mathrm{kg}$ bw

2 to 4 - Effect of AEH to $6.51 \times 10^{-3} \mathrm{~g} / \mathrm{kg}$ bw (2); $1.89 \times 10^{-2} \mathrm{~g} / \mathrm{kg}$ bw (3); $3.75 \times 10^{-2} \mathrm{~g} / \mathrm{kg}$ bw (4) (second arrow) preceded by the effect of the Adr to $2.5 \times 10^{-5} \mathrm{~g} / \mathrm{kg}$ bw (first arrow).

\section{B - Reduction of Hypertension Induced by Adrenaline in Function of the Dose of Heliotropium indicum}

The values express the pressure reduction percentages relative to control (Mean $\pm \mathrm{SEM} ; \mathrm{n}=3$; $* \mathrm{P}<0.05 ; * * \mathrm{p}$ $<0.01, * * * \mathrm{p}<0.001)$.

AEH between $6.51 \times 10^{-3}$ and $3.75 \times 10^{-2} \mathrm{~g} / \mathrm{kg}$ bw strongly inhibits hypertension induced by adrenaline

In the presence of $\mathrm{AEH}$ to increasing doses of between $6.51 \times 10^{-3} \mathrm{~g} / \mathrm{kg}$ bw and $3.75 \times 10^{-2}$ $\mathrm{g} / \mathrm{kg}$ bw adrenaline at the dose of $2.5 \times 10^{-5}$ $\mathrm{g} / \mathrm{kg}$ bw, Adr induced hypertension whose amplitude is less significant, ranging from $40 \pm 3.66 \mathrm{~mm} \mathrm{Hg}$ to $10 \pm 2.39 \mathrm{~mm} \mathrm{Hg}$. This 
corresponded to $47.37 \% \quad(\mathrm{p}<0.001)$ and $73.63 \%(p<0.001)$ decrease in the level of hypertension. These hypertensions were followed by hypotension to $20 \pm 2.85 \mathrm{~mm}$ $\mathrm{Hg}$ at doses of greater than or equal to $3.75 \times 10^{-2} \mathrm{~g} / \mathrm{kg}$ bw of AEH. The histogram of Figure 4 reflects the average variations ( $\mathrm{n}$ $=4$ ) in the level of adrenaline induced hypertension in rabbits according to the dose of AEH.

AEH between $3.1 \times 10^{-4}$ and $3.75 \times 10^{-2} \mathrm{~g} / \mathrm{kg}$ bw, induced a dose-dependents ustained hypotension. Further, this crude extract significantly reduced blood pressure induced by adrenaline to $2.5 \times 10^{-5} \mathrm{~g} / \mathrm{kg}$ bw.

These results indicate that $\mathrm{AEH}$ has an antihypertensive potential. They justify the traditional use of Heliotropium indicum to treat hypertension.

The hypotensive effects of AEH are comparable to those of african medicinal plants such as Ceasalpinia bonduc (Ceasalpinaceae) (Datte et al., 2004), Swartzia madagascariensis (Ceasalpinaceae) (Soro et al., 2004) and Zanthoxylum zanthoxyloïdes (Rutaceae) (Zahoui et al., 2010).

Under similar experimental conditions Abo et al., (1998) and Datte et al., (2004) showed that aqueous extracts of Mareya micrantha (Euphorbiaceae) and Ceasalpini abonduc (Ceasalpinaceae) contain cholinomimetic substances which induce hypotension in the rabbit between $5 \times 10^{-6}$ and $5 \times 10^{-2} \mathrm{~g} / \mathrm{kg}$ bw range concentrations comparable to that of AEH.

The hypotensive effect of AEH could therefore be related to the presence of cholinomimetic substances in this extract.
Indeed, it is known that acetylcholine induced on blood pressure in a dosedependent hypotension (Belemtougri et al., 2001).

The ionic mechanisms responsible for cholinergic excitation involves an increase in potassium conductance (Parkington et al., 2002) and a reduction of the slow calcium current (Gielsand Noble, 1976; Wang et al., 2004). Hypotensive active principles of AEH could act according to the same mechanism of action.

\section{References}

Abo, K.J-C., Aka, K.J., Ehile E.E.,Traore, F., and Guede-Guina, F. 1998. Effets cholinergiques de la fraction 2 (F2) d'un extrait aqueux de Mareya micrantha (MAR) sur la pression artérielle et l'activité cardiaque. Ann. Univ; Benin, Sér. Sciences, Tome XIV : 57-76.

Adjanohoun, E.J., and Ake A.L. 1979. Contribution au recensement des plantes médicinales de Côte d'Ivoire. Centre National de Floristique de l'Université Nationale de Côte d'Ivoire. $(C N F)$, Tome $1,23(30): 358$ pages.

Belemtougri, R., Mounanga, C., Ouedraogo, Y., and Sanogo, L. 2001. Effects de l'extrait aqueux total de Lantana camara L; (Verbenaveae) sur la pression artérielle de lapin. Rev. Méd. Pharm. Afr., 15: 1-13.

Bouquet and Debray. 1974. Plantes médicales de la Côte d'Ivoire. ORSTOM, Paris, 232 pages.

Datte, Y.J., Yapo, A.P., Kouame K.G.G., Kati, C.S., Amoikon, K.E., and Offoumou, A.M. 2004. Lead extract of Caesalpinia bonduc (Caesalpiniaceae) induces an increase of contractile force in rat skeletal muscle in situ. Phytomedecine, $11: 235-241$.

Giels, W.R., and Noble, S.J. 1976. Changes in membrane current in bullfrog atrium 
produced by acetylcholine. J.l of Physiol., 261: 103-123.

Kalanda and Omasombo 1995.Contribution à la connaissance des plantes médicinales du Haut Zaïre : plantes utilisées dans le traitement des maux d'estomac dans la ville de Kisangani. Rev. Méd. Pharm. Afr., .9 (1): 59-69.

Kamanzi, A.K., Kone, M., and Traore, D. 2002. Activités larvicide et molluscicide des plantes médicinales de Côte d'Ivoire. Bioterre, $\mathrm{N}^{\circ}$ special: $23-29$.

Keita S.M., Arnason, J.T., Baum, B.R., Marles, R., Camara, F., and Traore, A.K. 1999 Etude ethnopharmacologique traditionnele de quelques plantes médicinales anthelminthiques de la Haute Guinée (République de Guinée). Rev. Méd. Pharm. Afr., 13: 49-65.

Parkington, H.C., Evans, R.G., Coleman, H.A., and Tare, M. 2002. Role for endothelium-derived hyperpolarizing factor in rat mesenteric and hindlimb circulation in vivo. J. Physiol. (London), 542: 929-93.

Rao, S., Shaw, R., Brindis, R., Klein, L., Weintraub,W., and Peterson, E. 2006. On versus off label use of drug eluting Coronary Stents in Clinical Practice (Report from the American College of Cardiology National Cardiovascular Data Registry [NCDR]). Am. J. Cardiol., 97 (10): 1478 - 1481 .

Reddy, J.S., Rao, R.P., and Reddy, M.S. 2002. Wound healing effects of Heliotropium indicum, Plumbaco zeylanicum and Acalipha indica in rats. $J$. Ethnopharmacol., 79 : 249-251.
Soro, Y.T., Traore, F., Zahoui, O.S., and Kone, P.P. 2004. Effets pharmacologiques de Swartzia madagacariensis (Caesalpiniaceae) sur le système cardiovasculaire de Mammifères. Rev. Méd. Pharm. Afr., 18: 59-70.

Srinivas, K., Rao,M.E.B., and Rao, S.S. 2000. Anti-inflammatory activity of Heliotropium indicum Linn and Leucas aspera Spreng. in albinos rats. Indian J. Pharmacol., 32: 37-38.

Srinivasan, D., Nathan, S., Suresh, J., and Perumalsamy, P.L. 2001. Antimicrobial activity of certain Indian medicinal plants. J. Ethnopharmacol., 74: 217-220.

Traore, F., Zahoui, O.S., Nene-Bi, A., and Kone, P.P. 2007. Effets pharmacologiques de Heliotropium indicum (Boraginaceae) sur la respiration et le système cardiovasculaire de Mammifères. Rev. Méd. Pharm. Afr., 20 : 79-91.

Wang, G.J., Liao, J.F., Hintz, K.K., Chen, W.P., Su, M.J., Chen, C.F., and Ren, J. 2004. Calcium-antagonizing activity of S-petasin, a hypotensive sesquiterpene from Petasites for mosarrus, on inotropic and chronotorpic responses in isolated rat atria and cardiac myocites. Naunyn Schmiedebergs Arch. Pharmacol., 369 (3): 322-329.

Zahoui, S.O., Zirihi, N.G., Soro, Y.T., and Traore, F. 2010. Effet hypotenseur d'un extrait aqueux de Zanthoxylum zanthoxyloïdes (Lam.) Waterman (Rutaceae). Phytothérapie 8:359-369.

\section{How to cite this article:}

ZAHOUI Ouga Stanislas, NENE BI Semi Anthelme, SORO Tianga Yaya and TRAORE Flavien. 2016. Hypotensive Effect of an Aqueous Extract from Heliotropium indicum Linn. 1753 (Boraginaceae). Int.J.Curr.Microbiol.App.Sci.5(2): 475-482. doi: http://dx.doi.org/10.20546/ijcmas.2016.502.053 